\title{
Designing High-Strength Concrete Using Products of Dismantling of Buildings and Structures
}

\author{
T. Murtazaeva ${ }^{1(\bowtie)}$, A. Alaskhanov ${ }^{1}$, M. Saidumov ${ }^{1}$, \\ and V. Hadisov ${ }^{1,2}$ \\ ${ }^{1}$ Millionshchikov Grozny State Oil Technical University, Grozny, Russia \\ tomamurtazaeva@mail.ru \\ ${ }^{2}$ Ibragimov Complex Research Institute, RAS, Grozny, Russia
}

\begin{abstract}
The paper presents an analysis of experience of using the products of dismantling of buildings and structures, the technology of recycling of secondary raw materials to produce secondary raw materials for concrete. We presented results of tests of heavy concrete based on filled binders using the products of processing of concrete and brick scrap.
\end{abstract}

Keywords: Building demolition products - Concrete scrap - Brick scrap Ecology $\cdot$ Recycling $\cdot$ Secondary aggregate $\cdot$

Fine ground aggregate filled with binder

\section{Introduction}

A great interest for application of the secondary product of crushing concrete scrap of dismantling buildings and structures, according to the authors of the paper, is related to the possibility of its application as a fine-milled mineral component in filled binders, based on the use of which it is possible to produce high-strength concrete, including monolithic high-rise construction (Bazhenov et al. 2011; Batayev et al. 2017; Murtazaev et al. 2009).

\section{Methods and Materials}

The following materials were used as raw materials for concrete: natural sand from the Chervlenskoye deposit, crushed stone from gravel of 5-20 $\mathrm{mm}$ fractions from the Argunsky and Sernovodsky deposits, imported crushed stone of a 5-20 mm fraction from granite-diabase rocks of the Alagirsky deposit of the Republic of North OssetiaAlania, local non-additive portland cement of brand PC 500 D0, plastification additives Polyplast and D-5. 


\section{Results and Discussion}

To obtain the optimal formulations of high-strength concrete (HSC) with the integrated use of local raw materials, including of technogenic nature, compositions of filled binders (FB) with fine-milled mineral filler of technogenic nature (MFTN) of HB-75:25 and HB-60:40grades, allowing to obtain high-strength cement stone with noticeably smaller pores and less shrinkage (Murtazaev et al. 2009; Udodov 2015; Murtazaev and Salamanova 2018).

From the test results of HSC based on FB, it can be seen that the dynamics of the strength of concrete on FB are noticeably different from the dynamics of the growth of concrete strength on Portland cement.

It was established that the process of durability of concrete on FB at an early age (1-3 days) is accelerated by 1.5-2 times. So, concrete on FB at the age of 1 day has a strength of about 33-36\% of the designed, and 3 days old - this indicator reaches $70 \%$. 7-day strength of concrete, produced using FB, is about $85-90 \%$ of the designed, which is significantly higher than traditional compositions on ordinary Portland cement. These indicators for concrete on Portland cement at the age of 1, 3 and 7 days are about 24, 35 and $70 \%$ of the designed strength, respectively.

\section{Conclusions}

The optimal formulations of highly mobile concrete mixtures were designed using local natural and technogenic raw materials with a grade of P5 cone sediment and persistence for more than $8 \mathrm{~h}$ to obtain HSC classes of compressive strength up to B60-B80 with unique performance properties.

\section{References}

Bazhenov YM, Bataev DK-S, Mazhiev KN (2011) Fine-grained concretes from recycled materials for the repair and restoration of damaged buildings and structures. FE "Sultanbegova Kh.S.”, Grozny, $342 \mathrm{p}$

Batayev DK-C, Saidumov MS, Murtazaeva TS-A (2017) Recipes of high-strength concretes on technogenic and natural raw materials. In: Materials of the All-Russian Scientific and Practical Conference Dedicated to the 60th Anniversary of the Building Department of Millionshchikov GSTU, 12-13 October 2017, Bisultanova P.Sh., Grozny, pp 109-117

Murtazaev S-AY, Bataev DK-S, Ismailova ZK (2009) Fine-grained concretes based on fillers from secondary raw materials. Comtechprint, Moscow, $142 \mathrm{p}$

Udodov SA (2015) Re-introduction of plasticizer as a tool for controlling the mobility of concrete mix. In: Proceedings of the Kuban State Technological University, no 9, pp 175-185

Murtazaev SAY, Salamanova MS (2018) Clinker-free binders based on finely dispersed mineral components. In: Collection: Conference Proceedings, pp 707-714 
Open Access This chapter is licensed under the terms of the Creative Commons Attribution 4.0 International License (http://creativecommons.org/licenses/by/4.0/), which permits use, sharing, adaptation, distribution and reproduction in any medium or format, as long as you give appropriate credit to the original author(s) and the source, provide a link to the Creative Commons license and indicate if changes were made.

The images or other third party material in this chapter are included in the chapter's Creative Commons license, unless indicated otherwise in a credit line to the material. If material is not included in the chapter's Creative Commons license and your intended use is not permitted by statutory regulation or exceeds the permitted use, you will need to obtain permission directly from the copyright holder. 